\title{
CARACALLA AND DACIA. IMPERIAL VISIT, A REALITY OR ONLY RUMOUR?
}

\begin{abstract}
The author is challenging the Romanian historiography's interpretation concerning the visit in 213 of the emperor Caracalla in Dacia, until to the northern frontier at Porolissum, where three inscriptions with identical text were considered as the building inscriptions of the stone fortifications of the fort from Pomet Hill. He is mentioning the new inscriptions from different part of the Roman Empire that offer today a better knowledge of the emperor's actions and journeys during year 213. The conclusion is that he travelled to Orient after October 213 when defeated the Alamanns over the border of Raetia, along the Danube frontier visiting military bases. The journey was probably on the same route as he already done in 202 with his father, but in the other direction, returning from Orient. That time is possible Septimius Severus, Caracalla and Geta were in Dacia, at Drobeta, Tibiscum and Ulpia Traiana Sarmizegetusa, as several inscriptions attest. For this reason, it is possible that in 213 Caracalla stopped for a short period at Drobeta and maybe went to Tibiscum to pray in the temple of Apollo. However, continuing the trip to Porolissum is impossible to imagine, the time being too short, as he arrived at Nicomedia on the $17^{\text {th }}$ of December 213. At the end of the article, the author rejects the theory of any connection between the tile-stamps of the seventh legion Gemina Felix from Leon and those of the third legion Gallica found at Porolissum with Caracalla's journey. Furthermore, the author also dismisses the idea that these vexillations were taken to Dacia to replace Dacian vexillations involved in the eastern expedition of Caracalla, as there is neither no any positive evidence nor other evidence for similar examples in the history of the Roman military expeditions (e.g., Trajan's Parthian war) .
\end{abstract}

Keywords: Caracalla, eastern expedition, legions, Dacia, inscriptions

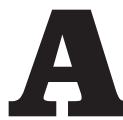

ncient written sources mention a visit of the emperor Caracalla in Dacia while he was ready to leave Danube frontier for the Oriental expedition. Historia Augusta is recording that Caracalla "dein ad Orientem profectionem parans omisso itinere in Daciam resedit". So he had no intention to go to Dacia, which was not on his way, but at a moment (we do not know exactly where was his location) something happened in Dacia (we do not know what) as he decided to change his route (omisso itinere) and go to Dacia. Cassius Dio is writing that the emperor arrived in Thrace, being not any more concerned about Dacia and crossed, not without danger, the Helespontus ${ }^{2}$. This source says only that he was at a moment concerned about Dacia (not necessary he travelled inside the province) and it is pointed the last European segment of his journey ${ }^{3}$. Obviously, he arrived in Thrace leaving one

\footnotetext{
SHA, Vita Caracallae, 5, 4.

2 Cassius Dio, LXXVII, 16, 7.

3 As a senator, he met the emperor in his homeland province Bithynia at Nicomedia, after 17 December 213, being better informed than $4^{\text {th }}$ century writer of Historia Augusta
}

\section{Coriolan Horațiu Opreanu}

Institute of Archaeology and Art History

Cluj-Napoca

choprean@yahoo.com

DOI: $10.14795 /$ j.v2i 2.107

ISSN 2360 - 266X

ISSN-L 2360 - 266X 
of the Danube's fortresses, as Novae, for example. The third source, Herodianus, is only mentioning that the emperor inspected the forts along the Danube, before arriving in Thrace $^{4}$. In conclusion, only Historia Augusta explicitly recorded a visit in Dacia, the others being more evasive. Many years archaeologists agreed this information trying to establish the exactly year when the emperor visit Dacia, AD 213, or AD 214? Recently, Hungarian Professor Szabó Ádám ${ }^{5}$ proposed a different and innovative interpretation to the sentence from Historia Augusta. He insisted that the text was written in the $4^{\text {th }}$ century and by "Dacia" the ancient author was probably meant Aurelian's south-Danubian Dacia Ripensis. Even his interpretation is not without logic, it is hard to understand by "Dacia" the $4^{\text {th }}$ century Dacia, as the emperor's concern about "Dacia" is also recorded by Cassius Dio who obviously understood by his statement the $3^{\text {rd }}$ century North-Danubian Dacia.

The visit in 213 was first supported by C. Daicoviciu. Then some important epigraphical evidence contributed to the development of the discussion. The editor was $\mathrm{M}$. Macrea ${ }^{6}$ who also did excavations at Porolissum in the Roman fort from Pomet Hill and on the Roman fort from the Citera Hill. He also published some earlier found construction inscriptions proving the building in stone of the fort from Pomet, or only of its gates, during Caracalla's reign. M. Macrea was convinced that the three construction inscriptions with identical text found at Porolissum in the excavation at three of the gates attest the complete building in stone of the fort's defence system because of the verb "fecit" and not only a reconstruction, nor only the building of the gates ${ }^{7}$. Recently, in a study dedicated to the building of the Roman forts in Dacia, F. Marcu considers the fort at Porolissum as built by Caracalla, although he admits that not all the inscriptions had a sure place of discovery ${ }^{8}$. M. Macrea proved to be cautious enough and very intuitive when did not exclude the existence of an earlier stone fort, maybe smaller, even there was no evidence known to him ${ }^{9}$. When later he wrote that the first stone phase of the fort from Pomet Hill took place in Antoninus Pius time ${ }^{10}$, he probably thought to the small fort from the Citera Hill where he excavated and in the northern tower of the northeast gate found a coin of Antoninus Pius in the mortar of the floor ${ }^{11}$.

The results of the excavations performed by A. Radnóti in 1943 at Porolissum have been published only in $1978^{12}$. Very important were few fragmentary inscriptions. The first one was found at porta principalis sinistra, dating from $\mathrm{AD} 129$, probably recording the building in stone of the gate, or of all the defence wall of the fort by cohors I Ulpia Brittonum ${ }^{13}$. Another inscription discovered at porta praetoria was reconstructed with the name of Antoninus

(DAVENPORT 2012, 802).

4 Herodian IV, 8, 1.

5 SZABÓ 2005.

6 MACREA 1957.

MACREA 1957, 226.

\& MARCU 2011, 128, n. 47.

9 MACREA 1957, 226.

10 MACREA 1969, 223.

11 MACREA/PROTASE/RUSU 1961, 374; GUDEA 1989, 91-92.

12 TÓTH 1978.

13 TÓTH 4/17 ; , 1978A-B.
Pius and dated in AD 140, or 140-144 ${ }^{14}$. Using this evidence, E. Tóth proposed the existence of a first partially stone phase under Hadrian, being finished for the whole fort under Antoninus Pius ${ }^{15}$. The certitude of the two stone phases of the fort Porolissum-Pomet resulted with no doubt from the finding of two construction inscriptions in porta principalis sinistra, one fragmentary from 129 , the other entire from 213 , and the same situation repeats at porta praetoria, with a fragmentary inscription from 140-144 and one from $213^{16}$.

N. Gudea the author of extensive excavations at Porolissum-Pomet (1977-2009) thinks it can be identified two big construction phases of the defence system, a turf and timber one ${ }^{17}$ and the phase with stonewalls built in $\mathrm{AD}$ 213, accepting two stone phases only for the headquarters building ${ }^{18}$. It cannot be established why N. Gudea ignores the inscriptions found by $\mathrm{A}$. Radnóti mentioned above. In spite of his 33 digging campaigns at Porolissum, N. Gudea did not succeed to excavate and publish not even one building from the fort and to establish the chronology of a closed complex. His hundreds of trenches cut over different buildings were not able to offer a correct plan of the fort. In conclusion, his theory of phases is based only on the inscriptions published by M. Macrea in 1957, without adding any relevant archaeological contribution.

In our opinion it is worth to observe that only the fort at Porolissum-Pomet have gates with projecting towers with rounded fronts, while the curtain towers are rectangular shaped and without front projecting. At the fort at Cășei for example, where the fort was built in stone only in the 3rd century, maybe under Caracalla, the curtain towers have projecting rounded fronts, being identically shaped as the gates' towers ${ }^{19}$. Similar situation as in Porolissum are known from North Africa at the fort from Remada where the principal gates have round-fronted towers, the initial ones being small internal gate towers and the precinct wall belonging to Hadrian's time ${ }^{20}$. These observations could mean that the curtain from Porolissum was not reconstructed in the 3rd century, only the gates being rebuilt. The curtain tower we have excavated is in topographic relation with the ballistarium building, so it belonged to the first stone phase from the 2nd century. It is true that we did not find any direct archaeological dating evidence inside the tower ${ }^{21}$.

The construction inscriptions of Caracalla do not mention what exactly was built, as is the case, for example, from the Roman fort at Bumbești ${ }^{22}$, it is not given any detail concerning the extent of the works (reparation, totally rebuilt of fort, or only of the gates ?), nor is written the name of the procurator, or of the governor. Usually, when in military

TÓTH 6/19 - 18,1978 ; recently I. Piso proposed a new reading which can date the inscription also in Hadrian's time, possible even in AD 129 (PISO 2013, 162-163).

15 TÓTH $9,1978$.

16 TÓTH 20 ,1978; Taf. V/8.

17 GUDEA 1997, 22-26.

18 GUDEA 1997, 33-35.

19 ISAC 2003, 114-120.

20 WELSBY 1990, 120.

1 OPREANU/LĂZĂRESCU/ȘTEFAN 2013.

${ }^{22}$ CIL III 14485 ("muros caespiticios castrorum coh(ortis) I Aureliae Brittonum (milliariae) Antoninianae vetustate dilapsos lapide eos restituerunt") 
inscriptions the name of the emperor is in Nominative case, it is considered as a sign of his direct interest, or that the work was done at his order and those who executed the work were in tight connection with $\mathrm{him}^{23}$. It is enough strange also the missing in the text of the inscription of the name of the military unit who executed the work, as happened in the text of the construction inscription from the first phase, where cohors I Ulpia Brittonum, the garrison of the fort, was nominated. If we add that this unit put another inscription to Caracalla having the epithet Antoniniana ${ }^{24}$, and cohors V Lingonum ${ }^{25}$ the same, is even more difficult to understand. The latter was also erected a bronze equestrian statue thanking in the inscription from its base for the advantages and gifts got from the emperor. It is hard to believe that the text of the construction inscriptions was transmitted directly by the emperor. They were executed at Porolissum with a text ordered by the procurator of the province Dacia Porolissensis, or by the consular governor from Apulum. It looks like these officials wanted a very general text, avoiding the association with the emperor not only of their own names, but also of the military unit who did the works, very probable the auxiliary permanent garrison of the fort. Is this a sign of carefulness, or is a case of extreme subservience? We only can appreciate that was an intentionally act.

F. Altheim believed Caracalla himself was present at Porolissum, followed by $\mathrm{C}$. Daicoviciu and finally by $\mathrm{M}$. Macrea, the last based on numerous epigraphical finds ${ }^{26}$. N. Gudea is also convinced that Caracalla did a "work visit" and that occasion Porolissum was the "military capital" of the Empire where the emperor delt with the barbarians and "the executions were enforced from the headquarters' tribunal", in a word, almost all the literary information we have happened in Porolissum ${ }^{27}$. But the peak of overstatements was reached by F. Marcu: "it would not be fanciful to imagine that Caracalla actually took part in the gates (or whatever it was) erection of Porolissum and the word fecit is per se"28. At Ulpia Traiana Sarmizegetusa, a construction plaque found in the first half of the 19th century at Nopcea manor from Zam, today in the museum from Deva (Romania) - similar in form and sizes with the inscriptions from Porolissum records the names of emperors Septimius Severus, Caracalla and Geta in Nominative case. It is followed only by the verb

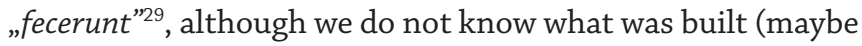
a gate of the town?)

If most of the old Romanian scholars agreed the visit of Caracalla, much debate was concentrated upon the year of the visit. First of all M. Macrea dated the construction building at Porolissum before 6 October 213 because of the missing of the title Germanicus Maximus and imperator $I I I^{30}$. Recently, F. Marcu, without any footnote, dated the inscriptions at the end of 213 and in $214^{31}$. Long time ago, J. Fitz made the observation that the inscriptions dedicated to

${ }^{23}$ HORSTER 2001, 44.

24 MACREA 1957, 228, n. 52.

${ }_{25}$ CIL III, 7638; TÓTH 1978, nos. 12, 46.

26 MACREA 1957, 240.

27 GUDEA 1997, 47-48.

28 MARCU 2011, 128.

29 CIL III 1451=IDR III/2, 21.

30 MACREA 1957, 224.

31 MARCU 2011, 128.
Caracalla from the first half of the year 213 do not contain the title of proconsul, which in his opinion means that the emperor was still in Rome ${ }^{32}$. In this respect, the inscriptions from Porolissum and the moment when the works were finished can be placed in the second half of 213, but no later than 6 October. It is not easy to estimate the period covered by the works. But it cannot be excluded the possibility that the start of the works was during the commune reign of Caracalla and Geta, or even before 212 when Septimius Severus was alive and as we seen others constructions were done in Dacia at the order of the three emperors ${ }^{33}$. What is sure is the end of the building activity, after Geta's death. If our presumption is correct it is possible to explain the attempt of the procurator, or of the governor to stress, by mentioning only the name of Caracalla and the verb "fecit" that nobody pretend to share with the emperor any imperial decision (maybe taken together with his younger brother).

Trying to establish the historical facts of that period, we need to get a deeper insight into the sources concerning Caracalla's activities in 213. In AD 212, the emperor was in Rome. He killed Geta at the end of February. A period of terror followed in Rome and in the provinces, 20 000 people being killed, as Cassius Dio recorded ${ }^{34}$. Sometime during the spring of 213, Caracalla left Rome for Gaul. In Gallia Narbonensis the milestones near Nice were raised between 1 January-6 October $213^{35}$ and the governor of the province was put to death by Caracalla ${ }^{36}$. From here, followed the Rhone valley towards Upper Germany reaching Mogontiacum (Mainz) on the Rhine, the traditional Roman operation base in Barbaricum. Then he stopped at Aquae (Baden-Baden) and in the fort at Abusina (Eining) ${ }^{37}$. Acta Fratrum Arvalium recorded that on the $11^{\text {th }}$ of August 213 the emperor arrived at the frontier of Raetia and crossed it in Barbaricum ${ }^{38}$. The same source mentions that on the $8^{\text {th }}$ of October 213 in Rome, on the Capitolium was hailed the Victoria Germanica of Caracalla ${ }^{39}$. Recently was established that the inscriptions from Pannonia recording an expeditio Germanica, or a bellum Germanicum are related to the same expedition against the Alamanni who invaded Raetia ${ }^{40}$. Caracalla's route after the ending of this war is pointed by several honorary inscriptions in the forts along the Danube frontier. It is about some special inscriptions, having a strong propagandistic message and showing the obedience of the army to Caracalla. There are stone inscriptions written with gilded bronze $10 \mathrm{~cm}$ high letters masoned in the gates' towers. Thus, in the fort from Holzhausen (Taunus, Hessen) were found fragments of two such inscriptions, one at porta principalis sinistra, the other at porta praetoria. The same in the fort at Saalburg, but also at Traismauer (Augustiniana), in Noricum, also at one of the gates. Fragments of gilded

32 FITZ 1966, 202 who mentions the inscription CIL XI 2086=ILS 451 dating on the $3^{\text {rd }}$ of May 213.

${ }^{33}$ See, n. 26.

${ }_{34}$ Cassius Dio, LXXVII, 4,1.

35 KRÓLCZYK 2011, 210.

36 SHA, Caracalla 5. 1 "Narbonensem proconsulem occidit"

KRÓLCZYK 2011, 211.

38 SCHEID 1998 Fr. 99 a : “...per limitem Raetiae ad hostes extirpandos barbarorum terram introiturus est...".

${ }^{39}$ SCHEID 1998 Fr. 99 a : “..ob salutem victoriamque Germanicam...”

40 MRÁV/OTTOMÁNYI 2005, 203-205. 
bronze letters were found in many other forts, but the most relevant find comes from Intercisa ${ }^{41}$, as it shows the way along the Danube of the emperor after 8 October 213. Obviously that this is the inspection of the units and forts of the Danube frontier recorded by the literary sources ${ }^{42}$. Topographic point of view is valuable a fragment from Cassius Dio which says that the emperor arrived in Thrace „but he was not any more concerned about Dacia” ${ }^{43}$. It results clear that he had a problem in Dacia, which was solved meantime. We do not know if he had to go to Dacia, or acted from distance while he was at Aquincum, Intercisa, or even Drobeta $^{44}$. As he arrived in Thrace after had some problems in Dacia seems he continued the journey on the Danube at least until Novae, where the legion I Italica was important for his expedition in Orient. Finally when crossed the sea, to Asia he luckily escape from a wrecking, when his ship was damaged by tempest in Helespontus ${ }^{45}$. But the most relevant epigraphic document to our discussion is the new fragment from Acta Fratrum Arvalium which attests the presence of Caracalla in his winter headquarters at Nicomedia as early as 17 December $213^{46}$ and not only in the next winter as was supposed before. In conclusion, Caracalla travelled from the frontier of Raetia to Nicomedia between the $8^{\text {th }}$ of October and the $17^{\text {th }}$ January 213 . Now the question is if in that period of approximately two months is room for a travel from the Danube to Northern Dacia, at Porolissum and back. In this new light year 214 is out of discussion. As it seems the emperor was at Intercisa, a direct crossing of the Hungarian plain to Porolissum from Aquincum is less probable. The rainy days of November and the dangerous crossing through the Iazyges territories exclude in our opinion such a possibility. Thus, the only reasonable variant remains a travel from Drobeta along the imperial road to inner Dacia.

Very useful in our attempt to reconstruct Caracalla's journey through Danubian provinces towards Asia Minor from 213 is the information we have concerning another travel of the imperial family in 202 when Septimius Severus and sons were travelling back from Orient and Egypt crossing Moesia and Pannonia ${ }^{47}$. The emperor was directing to Carnuntum to feast at 9 April 202 his ten years of reign, inaugurating on his way many roads, bridges, public and religious buildings ${ }^{48}$. He passed Augusta Traiana in Thrace and then from Philippopolis crossed Haemus Mountains to Nicopolis ad Istrum, recently transferred in Lower Moesia. It is not sure he continued the journey along the Danube, but there is good reason to consider he visited Novae, as legio I Italica was the first unit acting against Pescennius Niger

41 MRÁV 2001-2002, 229.

42 Herodian, IV, 7, 2; IV, 8, 1.

${ }^{43}$ Cassius Dio, LXXVII, 16, 7

${ }_{44}$ Drobeta could have been of interest for Caracalla, as the town was promoted to the status of colonia by Septimius Severus sometime between 198 and 209 (cf. MRÁV 2013, 218-219).

${ }_{45}$ SHA, Caracalla, 5, 8: "Per Thracias cum praefecto praetorii iter fecit. Inde cum in Asiam traiceret, naufragii periculum adiit antemna fracta, ita ut in scapham cum protectoribus descenderet. Unde in triremem classis receptus evasit"

46 SCHEID 1998, Fr. 99 b, 445.

47 Herodian III, 10, 1.

${ }^{48}$ CAH 2005, 247. who controlled the Bosphorus. Next information we have is that he arrived in 18 March 202 at Sirmium, then continued to the North on the Danube, passing Intercisa ${ }^{49}$ and very probable Aquincum and finally Carnuntum, both getting from the emperor the status of colonia $^{50}$. As also Drobeta was granted with the rank of colonia between 198 and 20951, it is very probable this event happened during Severus journey from 202. That means it is realistic to think he came from Novae on the Danube to Drobeta. Another inscription from Iaz-Tibiscum ${ }^{52}$ dedicated to Apollo is pro salute dominorum nostrorum Septimius Severus, Caracalla, Geta and the governor of the three Dacias L. Octavius Iulianus, dating between 200 and $202^{53}$. At Ulpia Traiana Sarmizegetusa a construction plaque found in the first half of the 19th century at Nopcea manor from Zam, today in the museum from Deva (Romania), records the names of emperors Septimius Severus, Caracalla and Geta in Nominative case, followed only by the verb „fecerunt” and it was dated between 200 and $209^{54}$. Usually, when in inscriptions the name of the emperor is in Nominative case, it is considered as a sign of his direct interest, or that the work was done at his order and those who executed the work were in tight connection with him $^{55}$. It is very plausible that the building was inaugurated in 202. Even not recorded in the written sources a journey of Septimius Severus from Drobeta to Ulpia Traiana Sarmizegetusa has logic ${ }^{56}$. It is highly probable that ten years later, in 213 Caracalla reconstruct on the other direction the itinerary done together with his father. It had the same reasons to do this: he needed political support of the army and communities from the provinces after dubious death of Geta and was marching along the military roads of the Danubian provinces gathering troops from the legions that were loyal to his father. We can guess that while still in Pannonia, probably around the beginning of November 213 (maybe at Sirmium), something happened concerning Dacia and he decided to action. He had to pass Singidunum and maybe Viminacium before arriving in Drobeta. That means he was already in Dacia. The question is if he resolved the problems of Dacia from Drobeta, or he continued his trip on the military road to Tibiscum, Ulpia Traiana, Apulum, Potaissa, Napoca, Porolissum. We can only speculate, how many days were necessary for such a two-ways journey ${ }^{57}$.

9 CAH 2005, 247-248.

MRÁV 2013, 213-216.

MRÁV 2013, 218-219.

2 PISO/ROGOZEA 1985, 211-214, no. 1, Abb. 1; AE 1987, 848; ILD 199.

3 PISO/ROGOZEA 1985, 213.

54 CIL III 1451=IDR III/2, 21

5 HORSTER 2001, 44.

56 BOTEVA 2010, 234 affirms that the emperor's journeys to Lower Moesia and Thrace were much more numerous than that recorded by the written sources, based on regional complexes of commemorative coins issued by towns and on many honorary inscriptions.

57 Today there are $470 \mathrm{~km}$ on road between Drobeta and Porolissum, that is 317 Roman miles. The Roman army was marching during campaigns 12 miles a day (DIACONESCU 1997, 8), that means were necessary 26 days to cover this distance and the same to be back, without counting the stops. Certainly, the imperial court need more, if we only take into account the smaller length of daylight in November and the stops in towns and forts. In conclusion, a visit of Caracalla in Dacia is not possible to imagine in AD 213. 
Anyway once on the Danube at Singidunum and Viminacium area the province and the communities of Dacia probably ask him to come and did preparations to demonstrate their loyalty and obedience to the emperor. If we take into account than from Novae he had to walk in November-17 December and to cross the Haemus Mountains, not to mentions the stops in very loyal towns, as Nicopolis ad Istrum, for example, it doesn't seem realistic he travelled till to the North of Dacia, at Porolissum. Usually the passing of the imperial court with the army and the supplies was a complicated matter. It have to be planned in details with rest places and requisitions in advance from local communities, which slowing the march ${ }^{58}$. We can at least accept he, joined only by the praetorians, briefly visited the fanum of Apollo from Tibiscum, probably inaugurated together with his father in 202, to pray for his health and journey ${ }^{59}$, leaving the army and the logistics on the Danube line. The other known inscription from the shrine of Apollo at Tibiscum, raised to Apollo Conservator Maximus Sanctissimusque, put by the governor from Apulum L. Marius Perpetuus using the tribunus of cohors I Vindelicorum from Tibiscum, demonstrates at least that the visit was expected. Among the epithets of Apollo, Sanctissimus is related to the emperor, as he is named Dominus Noster Sanctissimus in an inscription from Apulum raised by the legatus of the 13th legion Gemina for the health of the emperor. ${ }^{60}$ Sanctissimus Antoninus Augustus in a honorary inscription from Porolissum raised by cohors $V$ Lingonum Antoniniana ${ }^{61}$ and Sanctissimus Imperator Antoninus Augustus on a honorary altar from Micia ${ }^{62}$.

However, what would have been the reason the emperor was obliged to come to Dacia? Obviously, something unexpected happened as he broke in his journey to Orient („omiso itinere”) and „was concerned” about Dacia as we have seen. The frontier of Dacia was more difficult to be inspected compared with the Danube limes. The dealing with the barbarians from North-West Dacia and the taking of hostages were rutine operations, often mentions in the written sources during the Marcomannic wars as being executed by the governor of Dacia, in the name of the emperor. All this diplomatic activity seems to be decided by Caracalla from the imperial palace from Sirmium, or maybe from Drobeta. His presence at Sirmium is attested due to the receiving of an embassy of Ephesos ${ }^{63}$.

The expeditionary army which participated to expeditio Germanica and which was ready to go in Oriental expedition was composed of vexillations from different provinces among which the Danubian army was essential: legions I and II Adiutrix (Pannonia), IIII Flavia Felix (Upper Moesia), XI Claudia (Lower Moesia) ${ }^{64}$. The Dacian army so loyal to Septimius Severus was impossible not to participate.

58 CAH 2005, 244.

59 Cassius Dio LXXVII, 15, 5 is writing that Caracalla was ill and he spent nights praying in the temples of Apollo Grannus, Aesculap and Serapis. Many from his staff were obliged daily to bring gifts to gods and he himself was often coming, performing all the required rituals and hoping his own presence will help improving his health.

${ }_{60}$ CIL III 1129

${ }_{61}$ TÓTH 26,1978, nr. 12.

${ }_{62}$ IDR III/3, 55.

63 MRÁV/OTTOMÁNYI 2005, 205.

${ }^{64}$ MRÁV/OTTOMÁNYI 2005, 202.
Sign of the presence of the Dacian vexillations is that all the auxiliary units that raised honour inscriptions to Caracalla have the epithet Antoniniana, in Dacia being the most frequently used ${ }^{65}$. The most numerous inscriptions for Caracalla are in Dacia Porolissensis ${ }^{66}$. Two recently published inscriptions from the fortress of the fifth legion Macedonica from Potaissa ${ }^{67}$ are in honour of Caracalla and Iulia Domna. The dedicants are centurions from the legion placed in inscriptions by cohorts. In cohort I there were five centurions, while in cohorts II-X six in each. The hypothesis proposed for explaining the other centurions' absence affirms that a part of the subunits was left in vexillations. In this particularly case, I. Piso proposed they were left in Oriental expedition of Caracalla ${ }^{68}$. The chronology of the inscription is not well established, we do not know if the emperor received already the title of Germanicus Maximus, as presumed the editor. M. Bărbulescu does not totally reject Piso's idea, but he is wright when shows that if the absence of some subunits from Potaissa can be linked with the Oriental expedition they were sent before the supposed visit in Dacia of Caracalla ${ }^{69}$, which is not credible. We believe that the vexillation of the legion fifth Macedonica paticipated to the expeditio Germanica from summer-autumn 213 and was directing along the Danube frontier with the emperor towards the Orient. The fact that the subunits which remained at Potaissa raised honorary inscriptions mentioning, on one side the subunits presented in the fortress and on the other side the whole legion (universa legio) demonstrated that the emperor was not in Dacia, where Potaissa would have been an obligatory stop. In this view is less probable that legion VII Gemina from Leon to be attested at Potaissa ${ }^{70}$. The theory of bringing soldiers from the seventh legion from Hispania to substitute the Dacian vexillations left in Caracalla's Oriental expeditions is lacked by any documentary support. In $\mathrm{AD} 213$, it is impossible to think that a vexillatio of the legion VII Gemina was sent by Caracalla in a mission, as the legion seemed to be on Geta's side. Caracalla separated Hispania Taraconense in Hispania Superior and Hispania Nova Citerior Antoniniana, to have a better control of the governors. The new governor, C. Iulius Cerealis raised in the fortress at Leon an inscription to the emperor and his mother ${ }^{71}$. In another inscription, Ulpius Victor, a knight, has the position of praepositus of the seventh legion Gemina, just to keep an eye on this doubtful legion $^{72}$. As we showed before, to the Germanic expedition participated vexillations from all the Danubian provinces, but also to others more distant, as Britannia. Nowhere are recorded troops taken from other provinces to replace the local ones gone in the war outside their province. The legions of Pannonia from Aquincum and Brigetio, for example,

\footnotetext{
FITZ 1983, 61-66; 228, tab. 58.

BĂRBULESCU 2012, 141.

BĂRBULESCU 2012, nos. 10-11.

68 First time in 2003 at the Roman Frontier Studies Congress in Pécs (cf. BĂRBULESCU 2012, n. 243), last time in his lecture "Legion V Macedonica and the Parthian war of Caracalla" from 26 March 2015, Cluj-Napoca. After 12 years the idea did not achieve any documentary "improvement" and its renewal has no explanation.

69 BĂRBULESCU 2012, 141.

BĂRBULESCU 2012, nr. 21.

PALAO VICENTE 2006

2 CIL III 1464.
} 
were located on the limes where frequently disturbances has happened and it is not known if they were replaced by troops from other provinces. Even we would accept this hypothesis, another inscription from Potaissa records the seventh Gemina legion ${ }^{73}$ and not the VII Claudia (as we think is more natural). The inscription is dating based on the epithets Pia Constans of the legion V Macedonica after Commodus ${ }^{74}$, while the tile stamps L VII G F from Porolissum are dated before AD 197 due to the absence of the epithet Pia. ${ }^{75}$ Anyhow, they have no link with Caracalla's expeditions. The theory of moving legionary vexillations on thousands of kilometres just for replacing others departed in expeditions ${ }^{76}$, beside it is bereft of any literary support and is totally unworkable and impossible to be scheduled before, is suffering of a childish methodology ${ }^{77}$, difficult to be explained in actual context of the research on the interpretation of military tile stamps ${ }^{78}$. Nowhere in the Roman Empire was identified such a situation. As in the 15 years which passed from the first moment when I. Piso hypothesized this opinion did not emerge any supporting evidence, it have to be declared untrue and have to be rejected once and for all, even its author does not give up.

It is not sure if the tile stamps of the seventh legion were found together, in the same archaeological context with the tile stamps of the third legion Gallica. We did not find any in our excavations in the building B6. E. Tóth wrote the two stamps categories were found separately ${ }^{79}$. N. Gudea did not agree explaining that E. Tóth operated with a small number (20 bricks, 16 tiles) of this stamp only from the headquarters building, while in 2002 he speaks of more than 150 pieces discovered everywhere he excavated in the fort together with the seventh legion ones ${ }^{80}$. As the contexts mentioned by N. Gudea are not yet published, it is not at all sure who was right. There is no reason not to believe Tóth's conclusion for the situation in the headquarters building (even N. Gudea agrees).

N. Gudea briefly declared that in his trench which cut building B6 he found many tile stamps from the third legion Gallica and the seventh legion Gemina ${ }^{81}$, but any archaeological evidence of the contexts is missing from his publication. Concerning the date of the presence at

73 BĂRBULESCU 2012, nr. 21, who prefers the reading L VII G(emina)

74 PISO 2000, 219

75 LE ROUX 1982, 282-283.

76 Cf. PISO 2000, 208 a vexillatio of the third legion Gallica was brought at Porolissum between 195-197 when completed and fixed the fort from Pomet Hill.

77 Waiting the returning of the Dacian vexillations from Orient "les vexillations hispanique se seraient occupées le temps à compléter ou à réparer des installations militaires". But the author is suddenly awaken to reality and go on: "La datation du temps de Commode paraît pourtant, en raison des épithètes de la légion, plus probable" (PISO 2000, 220). However, in 2015 he forgot the last sentence he wrote himself 15 years ago. It is not an exaggerate effort as legionaries to be brought from two opposite sides of the Empire just to substitute some auxiliaries left in expeditions (but not attested in such a situation)?

78 KURZMANN 2006

79 TÓTH $46,1978$.

80 GUDEA 2002, 49

${ }^{81}$ GUDEA 1997, 41
Porolissum of the detachment of the third legion Gallica, E. Tóth was considering AD 231-260 ${ }^{82}$, while N. Gudea changed his mind several times till his final hypothesis was AD 213214 participating to the building of the fort defensive wall ${ }^{83}$. Finally, I. Piso appreciated that the third legion arrived at Porolissum in AD 195, leaving in AD $197^{84}$. Both Romanian scholars have considered that the detachment of the third legion Gallica was sent to Porolissum being „punished” by Septimius Severus for its unfaithful attitude during the civil wars. A cliché taken probably from Ovidius' exile at Tomis. In nowadays mentality of Romanian archaeologists, Porolissum is seen as a region more horrible than the Black Sea shore, the best place for somebody to be punished! Furthermore, N. Gudea thinks that an auxiliary unit from Syria (i.e. cohors III Dacorum) was either „punished” (there is no evidence at all for such action) together with the legion III Gallica and sent for 're-education' to Porolissum. N. Gudea repeated his old hypothesis last time in $2011^{85}$. Meanwhile, a wellknown specialist in Roman army of the Eastern provinces, E. Dabrowa, ${ }^{86}$ brought some fresh view to the subject, but he was ignored. His approach deals with the military colonisation of Syria during Septimius Severus ${ }^{87}$ rule focusing on the role of the third legion Gallica. Analysing the colonial coinage having depicted a vexillum with the name of the third legion Gallica he concluded the veterans of the legion were settled in Tyr (which became colony in AD 198), Sidon (which became colony in AD 221) and Acco-Ptolemaïs (new group of colonists in the old colony). Septimius Severus often used veterans from the third legion Gallica, not only in SyriaPhoenice, where was the permanent garrison of the legion, but also in the neighbour provinces. The legio III Gallica was exceptionally treated by Septimius Severus (in spite of his personal tide with legio IV Scythica he commanded in $\mathrm{AD}$ 180) just because of its loyalty in the war with Pescennius Niger. The legion also supported to the throne Elagabalus, considered being the son of Caracalla ${ }^{88}$. Thus, the third legion was loyal to Septimius Severus and his family, no evidence demonstrating the opposite. From a more credible hypothesis, we learn that the legion was banned later by Elagabalus who erased its name and officially condemned it by damnatio memoriae because the legion's commander Verus rebelled. ${ }^{89}$ Later, it was forgiven and restored as a legion of the Roman army by Severus Alexander ${ }^{90}$. If this was the ${ }^{82}$ TÓTH $47,1978$.

83 GUDEA 1999, 43-44; GUDEA 2002A.

${ }_{84}$ PISO 2000, 208.

${ }^{85}$ GUDEA 2011, 328.

86 DABROWA 2005.

87 On the same subject, see recently DABROWA 2012.

${ }_{88}$ Cassius Dio, LXXVIII, 31, 3 and 34, 2; Dabrowa 2005, 40-41.

89 Cassius Dio, LXXIX, 7, 1-3. Recently G. A. Diwan published a coin of Elagabalus issued by colony Sidon with the scene of the colonial foundation and the vexillum with the inscription LEG/III/ PAR(THICA). Another coin of the same type of Annia Faustina from AD 221 with a vexillum having only the inscription LEG III is used by the author to support the damnatio memorie suffered by Legio III Gallica and the bringing at Sidon of veterans from Legio III Parthica from Rhesaena (DIWAN 2013). The explanation is not totally convincing, as at Zeugma were identified also tile stamps with the inscription LEG III, considered a foreign legion, as Leg III Aug (see below, n. 56, SPEIDEL 2012, 614-616, n. 49).

90 DABROWA 2005, 42, n. 41. 
truth, it must have been for a short period as resulted from the chronology of the senatorial career of Q. Aradius Rufinus Optatus Aelianus who became commander of the third legion Gallica around AD 226 $6^{91}$. Thus, theoretically, the only possible period when legio III Gallica was disbanded officially is between $\mathrm{AD} 221$ when veterans of the legion were settled in the new colony Sidon and AD 225, as in 226 the legion was functional again. It is the only possible period when in Gudea's and Piso's view the soldiers of the legion could have been sent to Porolissum. But if the legion was disbanded and erased from the list of the army, why they were stamping tiles (an official action!)? It is a nonsense. Therefore, the period when a detachment of the third legion Gallica worked officially at Porolissum cannot be easily established ${ }^{92}$.

Conclusion.

Why was not possible to have legio VII Gemina garrisoned at Porolissum during the reign of Caracalla?

- The missing on tile stamps of the epithet Pia awarded in $\mathrm{AD}$ 197;

- The finding of the tile stamps in the first stone phase at principia (E. Toth), building B6 (C. Opreanu);

- The relations with Caracalla in Hispania - probably supporting Geta, change of the provincial organization, new governor, Ulpius Victor praepositus legionum VII G to watch an untrusted legion

- Obviously was taken to work at military installation as on Hadrian's Wall not to garrison an auxiliary fort while their unit was in vexillatio (not proved)

Why leg III Gallica was not at Porolissum in Caracalla's time?

- The inscription from Nahr-el-Kalb (Lebanon) - the name of the emperor at nominative "delatavit" the road by legio III Antoniniana sua

- Chronology, after 8 October 213 because of the title of Germanicus maximus. Being a road on the route to Oriental campaign ordered by the emperor the legion was there after 17 December 213 when Caracalla arrived at Nicomedia.

- Not possible for the emperor to go to Syria Phoenice and sending one of its legion to Porolissum to stay in garrison instead of some auxiliaries - see similar situation in Trajan's Parthian war, when vexillations from Dacian legions went to Orient and we have no information that some other troops from other provinces replaced them

In any situation talking today about a visit in Dacia of emperor Caracalla, crossing Dacia till the extreme north at Porolissum would be an anachronic approach, taking into consideration the new epigraphical finds from different provinces. Romanian historiography must giving up to useless stereotypes and to gathers the actual trends of discussion at European level. Otherwise, it risks to stay out, not integrated and seen with suspicion.

\section{REFERENCES}

BĂRBULESCU 2012

Bărbulescu, M., Inscripțiile din castrul legionar de la Potaissa (București: Academia Română).

BOTEVA 2010

Boteva, B. Roman Emperors Visiting the Danubian Province

\footnotetext{
91 DABROWA 1996, 283-284

${ }_{92}$ DABROWA 2000, 312.
}

of Lower Moesia: July 193-February 211. In: Zerbini, L. (ed.), Roma e le Province del Danubio. Atti del I Convegno Internazionale Ferrara-Cento, 15-17 Ottobre 2009 (Soveria CAH 2005 Mannelli: Rubbettino), 231-248.

Bowman, A.K./ Garnsey, P./ Cameron, A. (eds.), The Crisis of Empire AD 193-337 [Cambridge Ancient History 12] (Cambridge: University Press).

\section{DABROWA 1996}

Dabrowa, E., The Commanders of the Syrian legions, $1^{\text {st }} 3^{\text {rd }}$ c. AD. In: Kennedy, D./ Braund, D. (ed.), The Roman Army in the East [Journal of Roman Archaeology., Suppl. 18] (Ann Arbor Mi), 277-296.

DABROWA 2000

Dabrowa, E., Legio III Gallica. In: Le Bohec, Y./Wolff, C. (eds.), Les legions de Rome sous le Haut-Empire. Actes du Congrès de Lyon (17-19 septembre 1998) (Lyon: De Boccard), 309-315.

\section{DABROWA 2005}

Dabrowa, E., La legio III Gallica, la colonisation militaire et les Sévères. In: Beutler, F./ Hameter, W. (eds.), Eine ganz normale Inschrift. Festschrift zum 65. Geburtstag von Ekkehard Weber [Althistorisch-epigraphische Studien 5] (Wien: Eigenverlag der Österreichischen Gesellschaft für Archäologie), 135-143.

\section{DABROWA 2012}

Dabrowa, E., Military Colonisation in the Near East and Mesopotamia under the Severi, Acta Classica 55, 31-42.

\section{DAVENPORT 2012}

Davenport, C., Cassius Dio and Caracalla, The Classical Quarterly 62/2, 796-815.

\section{DIACONESCU 1997}

Diaconescu, Al., Dacia under Trajan. Some Observations on Roman Tactics and Strategy. In: Gudea, N. (ed.), Beiträge zur Kenntnis de römischen Heeres in den dakischen Provinzen. Veröffentlichung gelegentlich des 17. Internationalen Kongresses der Studien zu den Grenzen des Römischen Reiches, Zala冈u, September 1997 (Cluj-Napoca: Muzeul Național de Istorie a Transilvaniei), 5-44.

DIWAN 2013

Diwan, G.A., La IIIe Parthica, une nouvelle légion romaine á Sydon. OMNI 7, 116-120.

\section{FITZ 1966}

Fitz, J., When was Caracalla in Pannonia and Dacia?, Alba Regia 6-7, 202-205.

FITZ 1983

Fitz, J., Honorific Titles of Roman Military Units in the 3rd Century (Budapest: Akadémiai Kiado囚; Bonn: Habelt).

GUDEA 1989

Gudea, N., Porolissum. Un complex arheologic daco-roman la marginea de nord a Imperiului Roman I [Acta Musei Napocensis 13] (Zalău 1989).

GUDEA 1997

Gudea, N., Das Römergrenzkastell von Moigrad-Pomet. Porolissum 1. Castrul roman de pe vârful dealului PometMoigrad. Porolissum 1 (Zalău).

GUDEA 1999

Gudea, N./ Schuller, W. (eds.), Porolissum. Auschnitte aus der Leben einer dakisch-römischer Grebzieslung aus dem nordwestern der Provinz Dacia Porolissensis (Amsterdam)

\section{GUDEA 2002}

Gudea, N., Contribuții la istoria militară a Daciei Porolissensis. 7. Îndreptări în legătură cu legiunea III Gallica, Revista Bistriței 16, 47-54.

\section{GUDEA 2002A}

Gudea, N., Bezülich der Europäischen Wanderschaft 
der legio III Gallica zu Beginn der 3. Jh. In: Freeman, P./ Bennett, J./ Fiema, Z.T./ Hoffmann, B. (eds.), Limes XVIII. Proceedings of the XVIIIth International Congress of Roman Frontier Studies held in Amman, Jordan (September 2000) I (Oxford: Archaeopress), 19-24.

\section{GUDEA 2011}

Gudea, N., Contribuții la istoria militară a Daciei Porolissensis. 8. Alte îndreptări în legătură cu cohors III Dacorum. Apulum 48, 327-329.

HORSTER 2001

Horster, M., Bauinschriften römischer Kaiser. Untersuchungen zu Inschriftenpraxis und Bautätigkeit in Städten des westlichen Imperium Romanum in der Zeit des Prinzipats (Stuttgart: F. Steiner).

ISAC 2003

Isac, D., Castrul roman de la SAMVM-Cășeiu I. The Roman Auxiliary Fort SAMVM-Cășeiu (Cluj: Mega).

KRÓLCZYK 2011

Królczyk, K., Der Germanenfeldzug des Kaiser Caracalla im Lichte der epigraphischen Quellen. In: Ruciński, S./ Balbuza, C./ Królczyk, C. (eds.), Studia Lesco Mrozewicz. $A b$ amicis et discipulis dedicata (Poznań: Poznań : Instytut Historii UAM), 203-220.

KURZMANN 2006

Kurzmann, R., Roman Military Brick Stamps: a Comparison of Methodology [BAR I.S. 1543] (Oxford: Archaeopress).

LE ROUX 1982

Le Roux, P., L'armée romaine et l'organisation des provinces iberiques d'Auguste a l'invasion de 409 [Centre Pierre Paris 8] (Paris).

MACREA 1957

Macrea, M., Apărarea graniței de vest și nord-est a Daciei pe timpul împăratului Caracalla, Studii şi Cercetări de Istorie Veche 8/1-4, 215-251.

MACREA 1969

Macrea, M., Viața în Dacia romană (București: Editura Științifică).

MACREA/PROTASE/RUSU, 1961

Macrea, M./ Protase, D./ Rusu, M., Şantierul arheologic Porolissum, Materiale 7, 361-390.

MARCU 2011

Marcu, F., The Construction of the Roman Forts in Dacia, Dacia N.S. 55, 123-135.

MRÁV 2001-2002

Mráv, Zs., Eine litterae aureae-Inschrift aus Intercisa, Folia Archeologica 49-50, 207-233.

MRÁV 2013

Mráv, Sz., Septimius Severus and the Cities of the Middle Danubian Provinces. In: Eck, W./ Fehér, B./ Kovács, P. (eds.), Studia epigraphica in memoriam Géza Alföldi [Antiquitas 61] (Bonn: Habelt), 205-240.

MRÁV/OTTOMÁNYI 2005
Mráv, Zs./ Ottományi, K., De\{i\}fu(n)c(tus) exp(editione) Germ(anica) Lauri(aco) mort(e) sua. Sarkofag eines während der Alamannischen Expedition Caracallas verstorberen Soldaten aus Budaörs. Acta Archaelogica Academiae Scientiarum Hungaricae 56, 177-212.

\section{OPREANU 2013}

Opreanu, C.H., Corrigenda Porolissensia (I). Cohors III la Porolissum, Acta Musei Porolissensis 35, 177-190.

OPREANU/LĂZĂRESCU/STEFAN 2013

Opreanu, C.H./ Lăzărescu, V.A./ Ștefan, D., Noi cercetări la Porolissum, Analele Banatului 21, 83-106.

\section{PALAO VICENTE 2006}

Palao Vicente, J.J., Legio VII Gemina (Pia) Felix. Estudio de una legión romana (Salamanca: Ediciones Universidad).

PALAO VICENTE 2010

Palao Vicente, J.J., On the Concession of the title Felix to legio VII Gemina, Athenaeum 90/2, 437-444.

PISO 2000

Piso, I., Les légions dans le province de Dacie. In: Le Bohec, Y. (ed.), Les légions de Rome sous le Haut-Empire. Actes du congrès de Lyon (17-19 septembre 1998) (Paris: De Boccard), 205-225.

PISO 2013

Piso, I., Studia porolissensia III, Acta Musei Porolissensis 35, 159-176.

\section{PISO/ROGOZEA 1985}

Piso, I./ Rogozea, P., Ein Apolloheiligtum in der Nähe von Tibiscum, Zeitschrift für Papyrologie und Epigraphik 58, 211218.

\section{SCHEID 1998}

Scheid, J., Le protocole arvale de l'année 213 et l'arrivée de Caracalla à Nicomédie. In: Paci, G.(ed.), Epigrafia romana in area adriatica: actes de la IXe Rencontre franco-italienne sur l'épigraphie du monde romain : organizzata sotto il patrocinio dell'aiegl e del ministero degli affari esteri : Macerata, 1011 novembre 1995 (Pisa : Istituti editoriali e poligrafici internazionali), 339-451.

SPEIDEL 2012

Speidel, M.Al., Legio III Augusta in the East. Evidence from Zeugma on the Euphrates. In: Cabouret, B./ Groslambert, A./ Wolff, C. (eds.), Visions de l'Occident romaine. Hommages á Yann Le Bohec 2 (Paris: De Boccard), 603-619.

SZABÓ 2005

Szabó, A., Raetia oder Ratiaria? Caracalla...in Dacia resedit? Zu SHA, Ant. Caracalla V.4, Acta Antiqua Academiae TÓTH 1978 Scientiarum Hungaricae 43, 139-150.

Tóth, E., Porolissum. Das Castellum in Moigrad. Ausgrabungen WELSBY 1990 von A. Radnóti, 1943 (Budapest: Magyar Nemzeti Múzeum).

Welsby, D.A., Observations on the Defences of Roman Forts in North Africa, Antiquités Africaines 26, 113-129. 